\title{
International Competitiveness in the Economics Literature: A Bibliometric Study
}

\author{
By Magdalena Olczyk ${ }^{*}$
}

\begin{abstract}
This paper has as its main aim to consolidate the state of the art of academic research on international competitiveness, based on a bibliometric study of the economics literature published over the past 70 years. Citation data is collected from the ISI WEB of Science website, Scopus and Google Scholar and is analysed using Histcite and Vosviewer software. The growth pattern of the international competitiveness literature is investigated by using bibliometric indicators and co-citation analysis, and the core journals, authors and key international competitiveness research domains are identified. The results of the analysis show that international competitiveness is still an important and popular subject of studies in economics. Publications by Krugman, Fagerber and Balassa have made the greatest contributions to the development of international competitiveness concept. Journals with a general economic profile such as the American Economic Review, the Economic Journal and the Journal of International Economics have been most significant in terms of knowledge diffusion on international competitiveness. Additionally, co-citation analysis allows four main topics in international competitiveness research to be identified: skill \& innovation; place \& globalization; technology and environment.
\end{abstract}

Keywords: Bibliometrics, Co-citation analysis, Histcite, International competitiveness, Vosviewer

\section{Introduction}

International competitiveness is a key topic of interest for all, including managers, politicians and academics, especially as the globalization process is changing the competitive landscape. It has also become a central objective of national economic policies and strategies (e.g. Lisbon Strategy).

Despite its high popularity, international competitiveness is described as the most misunderstood concept in economics (Krugman 1994, De Grauwe 2010). A major problem is an abundance of definitions of it in the literature (Bhawsar and Chattopadhyay 2015). It is also a concept understanding of which comes from different disciples and covers a range of studies at various levels, i.e. mega, macro, mezzo and micro (Waheeduzzaman and Ryans 1996). All this means that the concept of international competitiveness is "elusive in so far as it neither has a well-defined meaning nor is it captured by unambiguous factors" (Cellini and Soczi 2002).

The debate on international competitiveness, which is based on a multitude of concepts, often without any explicit theoretical foundation, leaves a generally-accepted theory still missing (Lachmann 2001). According to Bofinger (1995) a main reason for this elusiveness is a lack of analysis of the interface between international trade theories and other theories, for example international monetary economic. The concept of international competitiveness is probably located within this interface region (Mitschke 2008).

\footnotetext{
* Assistant Professor, Gdansk University of Technology, Poland.
} 
There is, therefore, a need for a comprehensive review of the literature on international competiveness. The rare existing analyses by Chaudhuri and Ray (1997), followed by Banwet et al. (2002), Bhawsar and Chattopadhyay (2015) have provided a critical review of the literature. They all deal with definitions, measurements and sources of the various concepts in international competitiveness and always propose an integrated and eclectic approach, combining different schools of thought and multiple measurements as the most suitable way to study the subject. However, these analyses do not synthesize the existing literature and do not show the relationship between the different understandings of international competitiveness. Consequently, the aim of this paper is to fill this gap by using a new approach in this research area: bibliometric methods. According to the best knowledge of the author, an analysis of the international competitiveness literature using bibliometric methods has yet not been carried out.

The main aim of the paper is to consolidate the state of the art of academic research on international competitiveness by means of a bibliometric study of the literature published over the past 70 years. Citation data is collected from the ISI WEB of Science website, Scopus and Google Scholar and is analysed using HistCite and Vosviewer software. An analysis of the literature performed in this way may help to map and evaluate it, to identify potential research gaps and to highlight the boundaries of knowledge (Tranfield et al. 2003). This study has the following objectives: to investigate the growth pattern of the international competitiveness literature, and to identify the core journals, authors and key research domains in international competitiveness.

The rest of the paper is structured as follows. Next sections present the data and methodology, and also, provides the results of the estimations. Finally, the last section concludes.

\section{Data and Methodology}

The scientific research generated in the area of international competitiveness over the last 70 years has been much more than field researchers can be reasonably expected to review and know, even when the broadest area is subdivided. There is a lack of systematic, chronological and synthesizing studies indicating how the field has been institutionalized over time. This points to the possible usefulness of bibliometrics, based on the assumption that the essence of any scientific field is to produce "knowledge" and that scientific literature is the product or manifestation of that process (Okubo 1997).

Bibliometrics involves the application of mathematical and statistical methods to the analysis of scholarly publications (Pritchard 1969). Studies using bibliometric methods include a descriptive analysis of the growth of the literature and analyses of the productivity of authors and journals, of collaborations, of citations and of co-citations (Sangam 2008, Rao 2010, Andres 2009). 
The bibliometric methods and indicators used in this paper can be divided into two groups. First, I provide descriptive and citation analyses. Citation analysis is the examination of the frequency, patterns and graphs of citations, based on the assumption that the more a publication/author is cited by other publications/authors, the greater its influence on the discipline and the development of knowledge (Tahai and Meyer 1999). By using these bibliometric methods, I will identify changes in the scientific output, such as changes in the number of papers over time, and in the number of local and global citations related to the publications and authors ${ }^{1}$. Citation analysis using Histcite software will also enable the most relevant publications, authors and journals in international competitiveness research to be identified.

Second, I use a bibliometric method based on cited references, called cocitation analysis (Small 1973). Co-citation analysis is a relational technique which extends citation analysis by adding insight into the intellectual structure of a field of study (Benckendorff and Zehner 2013). The basis of co-citation analysis is that pairs of documents which often appear together in reference lists (i.e. are co-cited) are likely to have something in common. When two papers are frequently cited together there is a good likelihood that their ideas relate to each other. A list of all possible pairs of works cited among all citations in a given document enables a researcher to obtain the basic data for co-citation frequencies and co-citation networks.

Co-citation analysis has proved to be a useful empirical technique for describing the intellectual structure of disciplines such a services management (Pilkington and Chai 2008), tourism (Benckendorff 2009), open innovation (Wikhamn and Wikhamn 2013), higher education (Kosmützky and Krücken 2014), landscape and urban planning (Gobster, 2014) entrepreneurship (Ferreira et al. 2015), transportation management (Reinhold et al. 2015), hospitality management (García-Lillo et al. 2016a) and human management (García-Lillo et al. 2016b). It is common in these studies to limit the analysis of citations to papers published in the leading journals in a field or to based on Web of Science bibliometric data. Additionally, in all these studies macro-structure and the microstructure of a science is mapped, providing either overviews of research areas (topics) or a look at the underlying fine structures (Small 1999).

My co-citation analysis is conducted using Vosviewer software and its results are presented as a co-citation map. The creation of a co-citation map is a multi-step process. The Vosviewer mapping technique requires a similarity matrix as input. A similarity matrix can be obtained from a co-citation matrix by normalizing the latter. To normalize co-citation data Vosviewer uses an association strength index. The items identified are then placed on a twodimensional map in such a way that items that have high similarity are located close to each other, i.e. Vosviewer minimizes function (1) subject to constraint (2):

\footnotetext{
${ }^{1}$ LCS: Local Citation Score - the number of citations of the paper within the collection created. GCS: Global Citation Score - the number of citations in Web of Science.
} 


$$
\begin{aligned}
& V\left(X_{1} \ldots \ldots . . X_{N}\right)=\sum_{i<j} S_{i j}\left\|X_{i}-X_{j}\right\|^{2} \\
& \frac{2}{n(n-1)} \sum_{i<j}\left\|X_{i}-X_{j}\right\|=1
\end{aligned}
$$

where, $\mathrm{n}$ denotes the number of nodes in a network, $\boldsymbol{X}_{\boldsymbol{i}}$ denotes the location of node $\mathrm{i}$ in a two-dimensional space, and $\left\|\boldsymbol{X}_{\boldsymbol{i}}-\boldsymbol{X}_{\boldsymbol{j}}\right\|$ denotes the Euclidean distance between nodes $\mathrm{i}$ and $\mathrm{j}$.

To cluster the items on co-citation maps, Vosviewer maximizes the function

$$
V\left(c_{1 \ldots \ldots} c_{n}\right)=\sum_{i<j} \delta\left(c_{i}, c_{j}\right)\left(s_{i j}-\gamma\right)
$$

where, $\boldsymbol{c}_{\boldsymbol{i}}$ denotes the cluster to which node $\mathrm{i}$ is assigned, $\boldsymbol{\delta}\left(\boldsymbol{c}_{\boldsymbol{i}} \boldsymbol{c}_{\boldsymbol{j}}\right)$ denotes a function that equals 1 if $\boldsymbol{c}_{i=} \boldsymbol{c}_{j}$ and 0 otherwise, and $\boldsymbol{\gamma}$ denotes a resolution parameter that determines the level of detail of the clustering (the higher ts, the higher the number of clusters).

For the purposes of this study a database is specifically constructed. The creation of a database is an essential component of a bibliometric study because it must contain the scholarly literature represented in the discipline analysed. The three databases most used for bibliometric research are the WoS, Scopus and Google Scholar, but consistency and accuracy vary widely between them (Bar-Ilan 2008, Kulkarni et al. 2009) ${ }^{2}$. In this study, I follow the methodology of bibliometric database choice proposed by Yang and Meho (2007), who suggest combining information from a variety of sources (databases) in the analysis to reduce the risk of the database not being representative or exhaustive. Yang and Meho also consider WoS the gold standard for bibliometric studies, although it is far from perfect (Yang and Meho 2007). Scopus and Google Scholar, which may assist in providing a more comprehensive picture of scholarly communication among researchers, should be treated as complementary sources.

In the first step, data for the analysis was collected from the ISI Web of Knowledge database on 11 March 2015. The question formulated was: "Topic: 'international competitiveness', refined by: Web of Science category: 'economics' and document types: articles, proceedings papers; timespan: all years. Indexes: sci-expanded, ssci \& hci, cpci-s, cpci-ssh". The search covered articles in scientific journals and conference publications that contained the phrase

\footnotetext{
${ }^{2}$ Web of Science covers 12,000 ISI-indexed journals from the year 1900. Scopus covers 20,000 peer-reviewed journals, including those published by Elservier, Emerald, Informs, Taylors \& Francis, Springer and Interscience, but it is limited to articles published after 1995. Google Scholar is an unpublished bibliometric database offered by Google, and currently it covers metrics of articles published during the years 2009-2013 (Kumar et al. 2015).
} 
'international competitiveness' in the title, abstract or the keywords. The findings concerned the years 1945-2014 in the scientific discipline 'economics' in the Web of Science Core Collection, i.e. in the Science Citation Index Expanded [SCIEXPANDED], the Social Sciences Citation Index [SSCI], the Conference Proceedings Citation index - Science [CPCI-S] and the Conference Proceedings Citation Index - Social Sciences \& Humanities [CPCI-SSH]. The total number of documents found was 1,067 . The results were then verified.

The second step was to make the same search in Scopus and Google Scholar, using the same filters for article titles, abstracts and keywords as in WoS. The results were saved in Endnote software and then analysis of affinity with the sampling from WoS was carried out. For further data processing, I chose only the records from Google Scholar and Scopus which had a minimum of 10 citations and had not previously been found in Web of Science. From the two additional databases I obtained 107 new publications related to international competitiveness. The final database consists of 1,174 records.

\section{Empirical Results}

The local database created consists of 1,174 publications by 1970 authors, which are published in 457 journals. The authors comes from 69 countries and represent 961 institutions. All the publications have a total of 27,502 references cited, and 1,055 local and 77,714 global citations. Figure 1 shows the distribution of the 1,174 published articles and their local citations over time.

Figure 1. Scientific Productivity in the International Competitiveness Literature in the Years 1960-2014

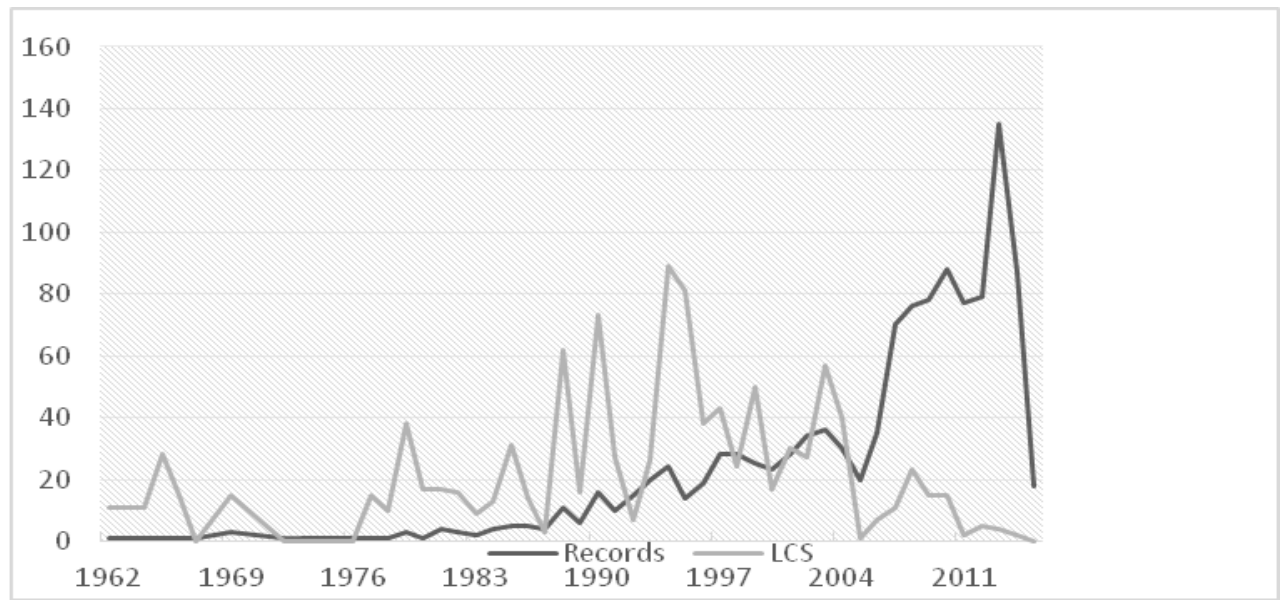

Source: Own calculations on the local database.

Analysis of Figure 1 indicates that research on international competitiveness was and still is an important and popular subject of study in economics. The first publications in the local database appeared in the 1960s, and over the next two and a half decades scientific interest in international competitiveness was small and limited to a few research papers annually. The first breakthrough was in 1988, when the annual number of publications reached the number published during the 
whole of the previous decade. A second one was in 1994 with a doubling of the number of works published annually on international competitiveness. However, the big boost in international competitiveness studies dates to 2007, when the number of annual publications again doubled compared to the previous year. This was mainly due to an explosion of competitiveness studies at the region and city levels and studies related to regulations, institutions and clustering processes and their impact on international competitiveness growth. In the next years, i.e. 20082014 , the number of publications related to international competitiveness ranged from 80 to 140 per year.

In contrast to the increasing number of publications related to international competitiveness, the number of citations grew until 1994 and then diminished. This may indicate two things. First, it is a natural phenomenon for articles to start to receive citations after a reasonable period of time after their publication, so it could take time until the new explosion in publications after 2007 results in an increasing number of citations. Second, one can hypothesize that the most important publications on international competitiveness were published two decades ago and the new publications do not contribute anything new. To verify this hypothesis, a ranking of the most-cited records in the local database is created (Table 1).

Table 1. Top 10 Papers Related to International Competitiveness

\begin{tabular}{|c|c|c|c|}
\hline Author & h-index & Title of publication/year & LCS \\
\hline Fagerberg J. & 38 & International competitiveness/1988 & 39 \\
\hline Krugman P.R. & 140 & $\begin{array}{l}\text { Competitiveness }- \text { A dangerous } \\
\text { obsession/1994 }\end{array}$ & 33 \\
\hline $\begin{array}{l}\text { Jaffe A., Peterson } \\
\text { S., Portney P., } \\
\text { Stavins R. }\end{array}$ & $\begin{array}{l}54 \\
90 \\
X\end{array}$ & $\begin{array}{l}\text { Environmental regulations and the } \\
\text { competitiveness of United States } \\
\text { manufacturing - what does the evidence } \\
\text { tell us/1995 }\end{array}$ & 29 \\
\hline Balassa B. & n.a. & $\begin{array}{l}\text { Trade liberalization and revealed } \\
\text { comparative advantage } / 1965\end{array}$ & 28 \\
\hline Tobey J. & 47 & $\begin{array}{l}\text { The effects of domestic environmental } \\
\text { policies on patterns of world trade - an } \\
\text { empirical test/1990 }\end{array}$ & 25 \\
\hline $\begin{array}{l}\text { Porter M.E., Van } \\
\text { der Linde C. }\end{array}$ & 128 & $\begin{array}{l}\text { Toward a new conception of the } \\
\text { environment-competitiveness } \\
\text { relationship/ } 1995\end{array}$ & 23 \\
\hline $\begin{array}{l}\text { Bander J.A., } \\
\text { Spencer B.J. }\end{array}$ & $\begin{array}{l}37 \\
26\end{array}$ & $\begin{array}{l}\text { Export subsidies and international market } \\
\text { share rivalry/1985 }\end{array}$ & 20 \\
\hline Barrett S. & 81 & $\begin{array}{l}\text { Strategic environmental policy and } \\
\text { international trade/1994 }\end{array}$ & 18 \\
\hline Krugman P.R. & 140 & $\begin{array}{l}\text { Scale economies, product differentiation } \\
\text { and the pattern of trade } / 1980\end{array}$ & 17 \\
\hline Melitz M. & 25 & $\begin{array}{l}\text { The impact of trade on intra-industry } \\
\text { reallocations and aggregate industry } \\
\text { productivity/2003 }\end{array}$ & 17 \\
\hline
\end{tabular}

Source: HistCite calculation based on the local database.

Notes: LCS- citation number in the sample; h-index in Google scholar; n.a. - not available 
The most significant publication in the evolution of international competitiveness research is Fagerberg's "International competitiveness", in which the author identified technology and production capacity as more important factors for economic growth than price or cost changes (Fagerberg 1988). The second most important publication is Krugman's paper "Competitiveness - a dangerous obsession" on the unproductive discussion around international competitiveness, in which the author calls discourse about international competitiveness "discussion on the theory of foreign trade, dressed in a new rhetoric" (Fujita and Krugman 2003). It is hard not to agree with Krugman's thesis when analysing the remaining eight most-cited publications on international competitiveness in the local database. The authors mainly analyse the determinants of competitive advantages and patterns of international trade, such as trade liberalization (Balassa 1965), intra-industry effects (Melitz 2003), economies of scale, product differentiation (Krugman 1980), and regulations and environmental policy (Tobey 1990, Jaffe et al. 1995, Barrett 1994, Porter and Van der Linde 1995).

I analyse the local database not only to identify the most important publications on international competitiveness but also the most important authors. The importance of individual authors in the development of research on international competitiveness can be assessed on the basis of the number of citations of their publications in the database created. First, I examine the distribution of the scientific productivity of all authors. Analysis of Table 2 confirms Lotka's statement that a small number of authors publish a large number of articles, while most authors can boast of only a few publications (Lotka 1926).

Table 2. Distribution of the Authors' Scientific Productivity in International Competitiveness Research

\begin{tabular}{|c|c|c|}
\hline Number of Authors & \% of Total Number of Authors & Number of Publications \\
\hline 1,807 & 91.73 & 1 \\
\hline 148 & 7.51 & $2-3$ \\
\hline 14 & 0.71 & $4-5$ \\
\hline 1 & 0.05 & $6-7$ \\
\hline 0 & 0.00 & $8>$ \\
\hline
\end{tabular}

Source: Own calculation based on the local database.

Second, using Histcite software I identified the authors with the largest number of citations. The results are strongly correlated with the ranking of most-cited publications (Table 1). With seven publications and sixty-eight local citations in the local database, the most-cited author is Krugman. The second most-cited is Fagerberg, who has four publications and fifty-two local citations. The third place in the ranking belongs to Balassa, who is cited 2.5 times less often than Krugman.

Publications in the local database containing "international competitiveness" in their title, abstract or keywords were published in 457 journals. Table 3 contains a list of the 10 journals with the highest number of citations in the local database. 
Among the most significant journals, those with a general economic profile dominate, such as the American Economic Review, the Economic Journal and the Journal of International Economics. They all are the journals with extremely high impact factor. The most frequently cited publications related to international competitiveness were published in these journals, e.g. Fagerber published in the Economic Journal, Krugman in the Journal of International Economics and Porter and Van de Linde in the Journal of Economic Perspectives. This general economic profile of journals is probably due to the fact that there is not a single journal in the JCR list which is exclusively dedicated to competitiveness/international competitiveness issues.

Table 3. The Most Significant Journals in Research on International Competitiveness

\begin{tabular}{|c|l|c|c|c|}
\hline \multicolumn{1}{|c|}{ Journal } & Records & LCS & ImF \\
\hline 1 & American Economic Review & 11 & 89 & 3,7 \\
\hline 2 & Economic Journal & 6 & 68 & 2,4 \\
\hline 3 & Journal of International Economics & 12 & 61 & 2,4 \\
\hline 4 & Journal of Political Economy & 6 & 50 & 3,6 \\
\hline 5 & Journal of Economic Literature & 2 & 38 & 5,4 \\
\hline 6 & Kyklos & 3 & 38 & 1,3 \\
\hline 7 & $\begin{array}{l}\text { Weltwirtschaftliches Archiv - Review of Word } \\
\text { Economics }\end{array}$ & 38 & 0,7 \\
\hline 8 & $\begin{array}{l}\text { Journal of Environmental Economics and } \\
\text { Management }\end{array}$ & 9 & 36 & 0,9 \\
\hline 9 & Journal of Economic Perspectives & 2 & 35 & 4,9 \\
\hline 10 & Foreign Affairs & 1 & 33 & $\mathrm{x}$ \\
\hline
\end{tabular}

Source: HistCite calculation based on the local database.

Notes: LCS - citatation number in the sample, ImF- impact factor.

An important part of this article is the co-citation analysis of cited references. This method involves classifying the scientific literature into 'natural categories' which we can treat as research domains/topics. First, using Vosviewer software, highly cited references from the 1,174 publications in the local database are identified by taking as criterion at least 14 citations (the gold standard is between 10 and 15). Only 32 of the 27,502 references meet the threshold. Second, for each of the 32 cited references pairs of co-cited references are created and the number of co-citations is determined. Third, the number of co-citations as a similarity measure serves as an input in Vosviewer software for both mapping and clustering.

In Figure 2, a combined mapping and clustering of the most frequently cited references is shown based on their co-citation numbers in the field of international competitiveness analyses in the period 1960-2014. The clustering process shown in Figure 2 allows four research topics in international competitiveness studies to be distinguished. There are three clusters with almost the same number of homogeneous publications (6, 7 and 8 publications) and one cluster which is a little bigger with 11 publications. The publications 
are represented on the map by the name of the author. After examining these clusters in more detail, a summary of their contents can be provided in Table 4.

Cluster no. 1 can be named the "skill \& innovation cluster". In it are grouped homogenous publications mainly related to the role of knowledge, human capital and innovation in increasing international competitiveness. The most influential publications in this research area are by Krugman (1994), Porter (1990) and Nelson (1982), among others.

Cluster no. 2 (the "technology cluster") groups homogenous publications which draw attention to the level of technological development as a key factor enhancing the international competitiveness of economies (Fagerberg 1988). The main contributions to this research domain in international competitiveness studies are by Fagerberg (1988), Grossman and Helpman (1990) and Dosi et al. (1990).

Figure 2. Mapping and Clustering of the 32 Most-Cited References With Variable Co-Citation Strength

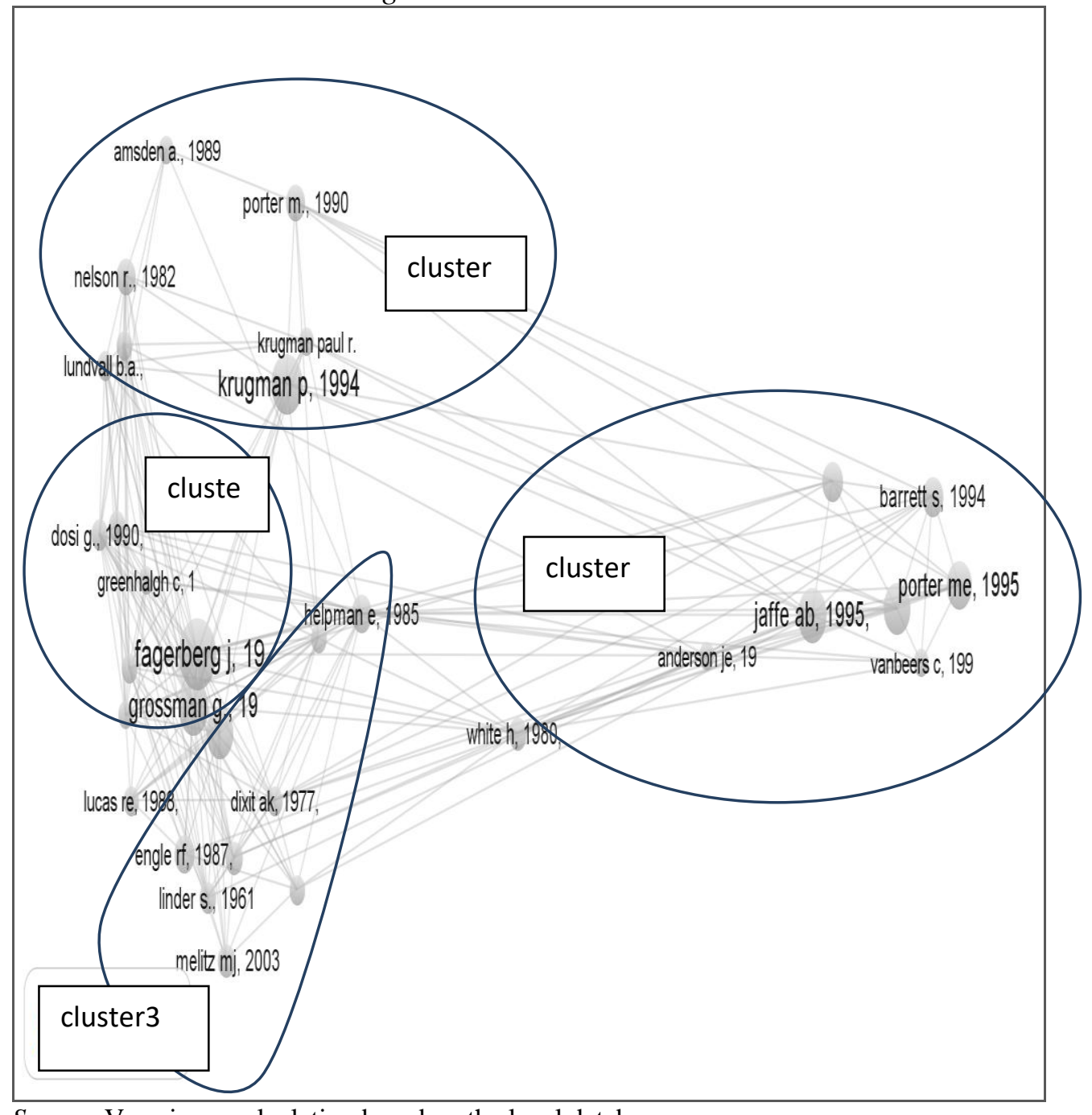

Source: Voswiever calculation based on the local database. 
The next cluster, no. 3 (the "location and globalisation cluster"), is located very close to cluster no. 2 on the map and is connected with it by a thick network of co-citation links. Here are grouped publications which focus on the impact of production location, production diversity, economies of scale and liberalisation processes (the power of regulation) on the growth of international competitiveness. The most important publications are written by Ballasa (1965), Krugman $(1979,1980)$ and Helpman and Krugman (1985).

Table 4. Summary of the Contents of the Four International Competitiveness Clusters

\begin{tabular}{|c|c|c|}
\hline \multicolumn{2}{|c|}{$\begin{array}{c}\text { Important authors } \\
\text { (number of citations/number of co-citations) }\end{array}$} & Main topics \\
\hline \multicolumn{3}{|c|}{ Cluster no 3 (11 publications) } \\
\hline $\begin{array}{l}\text { Armington } 1969(15 / 23) \\
\text { Balassa } 1965(28 / 19) \\
\text { Dixit and Stiglitz } 1977 \\
(15 / 27) \\
\text { Engle and Granger } 1987 \\
(19 / 14) \\
\text { Helpman and Krugman } \\
1985(19 / 61)\end{array}$ & $\begin{array}{l}\text { Krugman } 1980(17 / 46) \\
\text { Krugman } 1979(15 / 32) \\
\text { Linder } 1961(16 / 42) \\
\text { Lucas } 1988(15 / 32) \\
\text { Melitz } 2003(17 / 21) \\
\text { Romer } 1986(14 / 43)\end{array}$ & $\begin{array}{l}\text { place, location; } \\
\text { production diversity; } \\
\text { economies of scale; } \\
\text { development; } \\
\text { liberalisation; } \\
\text { regulation. }\end{array}$ \\
\hline \multicolumn{3}{|c|}{ Cluster no 4 (8 publications) } \\
\hline $\begin{array}{l}\text { Anderson } 1979(14 / 30) \\
\text { Barrett } 1994(20 / 48) \\
\text { Brander and Spencer1985 } \\
(20 / 27) \\
\text { Jaffe et al. } 1995(30 / 73)\end{array}$ & $\begin{array}{l}\text { Porter and Van der Linde } \\
1995(26 / 62) \\
\text { Tobey } 1990(28 / 61) \\
\text { Van Beers and Van den } \\
\text { Bergh } 1997(14 / 44) \\
\text { White } 1980(17 / 47)\end{array}$ & $\begin{array}{l}\text { environmental policy; } \\
\text { environmental } \\
\text { regulations; } \\
\text { domestic environmental } \\
\text { policy. }\end{array}$ \\
\hline \multicolumn{3}{|c|}{ Cluster no 1 (7 publications) } \\
\hline $\begin{array}{l}\text { Amsden } 1989(14 / 7) \\
\text { Krugman } 1991(14 / 25) \\
\text { Krugman } 1994(33 / 36) \\
\text { Lundvall } 1992(15 / 39)\end{array}$ & $\begin{array}{l}\text { Nelson } 1982(18 / 46) \\
\text { Porter } 1990(18 / 17) \\
\text { Vernon } 1966(15 / 52)\end{array}$ & $\begin{array}{l}\text { skills, knowledge, human } \\
\text { capital; } \\
\text { innovation \& growth. }\end{array}$ \\
\hline \multicolumn{3}{|c|}{ Cluster no 2 (6 publications) } \\
\hline $\begin{array}{l}\text { Amable and Verspagen } \\
1995(15 / 78) \\
\text { Dosi et al.1990 (16/74) } \\
\text { Fagerberg } 1988(40 / 140)\end{array}$ & $\begin{array}{l}\text { Greenhalgh et al. } 1994 \text { (14/ 53) } \\
\text { Grossman and Helpman } 1991 \\
(31 / 103) \\
\text { Posner } 1961(16 / 74)\end{array}$ & $\begin{array}{l}\text { technology; } \\
\text { technological factors of } \\
\text { growth; } \\
\text { technical changes. }\end{array}$ \\
\hline
\end{tabular}

Source: Voswiever calculation based on the local database.

The last cluster (the "environmental cluster") consists of publications which are not very closely related to the other three research domains represented by clusters $1-3$. The most significant publications in the analysis of international competitiveness growth via environmental policy and environmental regulation changes are by Jaffe et al. (1995), Tobey (1990) and Porter and Van der Linde (1995). 


\section{Discussion and Conclusions}

To the best of the author's knowledge, this analysis based on articles and conference publications on international competitiveness using titles, keywords and abstracts is the first of this kind of study carried out in the discipline of economics. The results of this study should be regarded as preliminary and requiring further analysis.

The analysis has confirmed that international competitiveness is still an important and popular subject of study in economics, even though the most significant publications were written almost three decades ago by Krugman, Fagerber and Balassa. Ranking of the most significant publications and authors in international competitiveness studies has revealed much diversity among the international competitiveness topics analysed. Co-citation analysis has allowed the most significant publications to be identified and clustered in homogeneous groups, which can be treated as the main research topics in international competitiveness studies. There are four main research domains in international competitiveness research: skill \& innovation; place \& globalization; technology; and the environment.

It is hoped, that results obtained will be an important voice in discussion on the defining and measurement of international competitiveness concept among disciples of economics. The study revealed the diversity of key topics within the concept analysed This abundance of key terms supports the eclectic approach to defining and measuring international competitiveness by combining different schools of thought and multiple measurements. The results also confirm those of Balkyte and Tvaronaviciene (2010) that international competitiveness is not just about technology or economic performance but should take into consideration the "soft factors" involved, such as the skills or environment.

Of course, further analyses are needed. Futures empirical analyses should concentrate on the relationship between the different understandings of international competitiveness, for example by using main path analysis.

\section{Acknowledgments}

This research has been conducted within a project financed by the National Science Centre (NCN), Poland (decision number DEC-2011/03/D/HS4/ 00861). Financial support from NCN is gratefully acknowledged.

\section{References}

Amable B, Verspagen B (1995) The role of technology in market shares dynamics. Applied Economics 27: 197-204.

Amsden A (1989) Asia's Next Giant: South Korea and Late Industrialization. New York: Oxford University Press.

Anderson J (1979) A Theoretical Foundation for the Gravity Equation. The American 
Vol. 2, No. $4 \quad$ Olczyk: International Competitiveness in the Economics Literature...

Economic Review 69(1): 106-116.

Andres A (2009) Measuring Academic Research: How to Undertake a Bibliometric Study. New Dehli: Chandos Publishing.

Armington P (1969) A Theory of Demand for Products Distinguished by Place of Production. International Monetary Fund Staff Papers 16(1): 170-201.

Balassa B (1965) Trade Liberalization and Revealed Comparative Advantage. Manchester School of Economic and Social Studies 33(2): 99-123.

Balkyte A, Tvaronaviciene M (2010) Perception of Competitiveness in the Context of Sustainable Development: Facets of "Sustainable Competitiveness". Journal of Business Economics and Management 11(2): 341-365.

Banwet DK, Momaya K, Shee HK (2002) Competitiveness: Perceptions, reflections and directions. IIMB Management Review 14(3/May): 105-116.

Bar-Ilan J (2008) Informetrics at the beginning of the 21st century - A review. Journal of Informetrics 2(1/February): 1-52.

Barrett S (1994) Self-Enforcing International Environmental Agreements. Oxford Economic Papers 46: 878-894.

Benckendorff P (2009) Themes and trends in Australian and New Zealand tourism research: A social network analysis of citations in two leading journals (19942007). Journal of Hospitality and Tourism Management 16(1): 1-15.

Benckendorff P, Zehrer A (2013) A network analysis of tourism research. Annals of Tourism Research 43: 121-149.

Bhawsar P, Chattopadhyay U (2015) Competitiveness: Review, Reflections and Directions. Global Business Review 16(4): 665-679.

Bofinger P (1995) Die internationale Wettbewerbsfähigkeit ganzer Volkswirtschaften: Ein Phänomen auf der Suche nach einer Theorie (The international competitiveness of entire economies: A phenomenon in search of a theory) Kredit und Kapital 28: 467-497.

Brander J, Spencer B (1985) Export subsidies and international market share rivalry. Journal of International Economics 18: 83-100.

Cellini R, Soczi A (2002) Pop competitiveness. Banca Nazionale del Lavoro Quarterly Review 55(March): 71-101.

Chaudhuri S, Ray S (1997) The competitiveness conundrum literature review and reflections. Economics and Political Weekly 32(48): 83-91.

De Grauwe P (2010) Introduction. In P. De Grauwe (Eds.) Dimensions of Competitiveness. Cambridge: MIT Press.

Dixit A, Stiglitz J (1977) Monopolistic Competition and Optimum Product Diversity. The American Economic Review 67(3): 297-308.

Dosi G, Pavitt K, Soete L (1990) The economics of technical change and international trade. London: Harvester Wheatsheaf.

Engle R, Granger C (1987) Co-integration and error correction: representation, estimation, and testing. Econometrica 55(2): 251-276.

Fagerberg J (1988) International Competitiveness. The Economic Journal 98(June): 55-374.

Ferreira M, Reis N, Miranda R (2015) Thirty years of entrepreneurship research published in top journals: analysis of citations, co-citations and themes. Journal of Global Entrepreneurship Research 5: 17-39.

Fujita M, Krugman P (2003) The new economic geography: Past, present and the future. Papers in Regional Science 83(1): 139-164.

García-Lillo F, Úbeda-García M, Marco-Lajara B (2016a) The intellectual structure of research in hospitality management: A literature review using bibliometric methods of the journal. International Journal of Hospitality Management 52: 121-130. 
García-Lillo F, Úbeda-García M, Marco-Lajara B (2016b) The intellectual structure of human resource management research: A bibliometric study of the International Journal of Human Resource Management, 2000-2012. The International Journal of Human Resource Management 4: 131-145.

Gobster PH (2014) Mining the LANDscape: Themes and trends over 40 years of Landscape and Urban Planning. Landscape and Urban Planning 126: 21-30.

Greenhalgh Ch, Taylor P, Wilson R (1994) Innovation and Export Volumes and Prices--A Disaggregated Study. Oxford Economic Papers 46(1): 102-35.

Grossman G, Helpman E (1990) Comparative advantage and long-run growth. The American Economic Review 80: 796-815.

Grossman G, Helpman E (1991) Innovation and growth in the global economy. Cambridge, Mass: MIT Press.

Helpman E, Krugman P (1985) Market Structure and Foreign Trade. Cambridge, Mass.: MIT Press.

Jaffe A, Peterson S, Portney P, Stavins R (1995) Environmental Regulation and the Competitiveness of U.S. Manufacturing: What Does the Evidence Tell Us? Journal of Economic Literature 33(1): 132-163.

Kosmützky A, Krücken G (2014) Growth or steady state? A bibliometric focus on international comparative higher education research. Higher Education 67(4): 457-472.

Krugman PR (1979) Increasing Returns, Monopolistic Competition and International Trade. Journal of International Economics 9(4/February): 469-479.

Krugman PR (1980) Scale Economies, Product Differentiation, and the Pattern of Trade. The American Economic Review 70(5): 950-959.

Krugman P (1991) Increasing Returns and Economic Geography. Journal of Political Economy 99: 483-499.

Krugman PR (1994) Competitiveness - A dangerous obsession. Foreign Affairs 73(2/March/April): 28-44.

Kulkarni AV, Aziz B, Shams I, Busse JW (2009) Comparisons of citations in Web of Science, Scopus, and Google Scholar for articles published in general medical journals. JAMA 302: 1092-1096.

Kumar A, Shivarama J, Choukimath PA (2015) Popular Scientometric Analysis, Mapping and Visualisation Softwares: An Overview. Retrieved from http://goo.gl/FfBkYD.

Lachmann W (2001) Improving the international competitiveness of nations. WEP Working Paper 6: 1-21.

Linder S (1961) An Essay on Trade and Transformation. New York: Wiley \& Sons.

Lotka AJ (1926) The frequency distribution of scientific productivity. Journal of the Washington Academy of Sciences 16(12): 317-324.

Lucas R (1988) On the mechanics of economic development. Journal of Monetary Economics 22(1): 3-42.

Lundvall B (Ed.) (1992) National Systems of Innovation: Towards a Theory of Innovation and Interactive Learning. London: Pinter Publishers.

Melitz MJ (2003) The Impact of Trade on Intra-industry Reallocations and Aggregate Industry Productivity. Econometrica 71(6/November): 1695-1725.

Mitschke A (2008) The Influence of National Competition Policy on the International Competitiveness of Nations: A Contribution to the Debate on International Competition Rules. Heidelberg: Springer.

Nelson R (Eds) (1982) The Government and Technical Progress. New York: Pergamon Press.

Okubo Y (1997) Bibliometric Indicators and Analysis of Research Systems: Methods 
Vol. 2, No. $4 \quad$ Olczyk: International Competitiveness in the Economics Literature...

and Examples. OECD Science, Technology and Industry Working Papers 1997/01: 6-69.

Pilkington A, Chai KH (2008) Research themes, concepts and relationships. International Journal of Service Industry Management 19(1): 83-110.

Porter ME (1990) The competitive advantage of nations. London: MacMillan.

Porter ME, Van der Linde C (1995) Toward a New Conception of the EnvironmentCompetitiveness Relationship. Journal of Economic Perspectives 9: 97-118.

Posner M (1961) International trade and technical change. Oxford Economic Paper 13(3): 323-341.

Pritchard A (1969) Statistical Bibliography or Bibliometrics? Journal of Documentation 25(4): 348-349.

Rao IK (2010) Growth of literature and measurement of scientific productivity. New Delhi: Ess Publication.

Reinhold S, Laesser C, Bazzi D (2015) The intellectual structure of transportation management research: A review of the literature. Working Paper Series 005. St. Gallen: SBB Lab.

Romer P (1986) Increasing Returns and Long-Run Growth. The Journal of Political Economy 94(5): 1002-1037.

Sangam SL (2008) Areas in the field of scientometrics and informetrics. In: M Koganuramath, BD Kumbhar, BS Kademani (Eds.) Library and information science profession in the knowledge society. New Delhi: Allied Publishers.

Small H (1973) Co-citation in the Scientific Literature: A New measure of the Relationship between Two Documents. Journal of the American Society for Information Science 24(4/February): 265-269.

Small H (1999) Visualizing science by citation mapping. Journal of the American Society for Information Science 50: 799-813.

Tahai A, Meyer MJ (1999) A revealed preference study of management journals' direct influences. Strategic Management Journal 20(3): 279-296.

Tobey J (1990) The effect of domestic environmental policies on patterns of word trade - an empirical test. Kyklos 43(2): 191-209.

Tranfield D, Denyer D, Smart P (2003) Towards a Methodology for Developing Evidence-Informed Management Knowledge by Means of Systematic Review. British Journal of Management 14: 207-222.

Van Beers C, Van den Bergh J (1997) An empirical multi-country analysis of the impact of environmental regulations on foreign trade flows. Kyklos, 50: 29-46.

Vernon R (1966) International investment and international trade in the product cycle. The Quarterly Journal of Economics 80(2): 190-207.

Waheeduzzaman AN, Ryans JK (1996) Definition, perspectives, and understanding of international competitiveness: A quest for a common ground. Competitiveness Review 6(2): 7-26.

White H (1980) A Heteroskedasticity-Consistent Covariance Matrix Estimator and a Direct Test for Heteroskedasticity. Econometrica 48(4): 817-838.

Wikhamn B, Wikhamn W (2013) Structuring of the open innovation field. Journal of Technology Management \& Innovation 8(3): 173-185.

Yang K, Meho L (2007) Impact of data sources on citation counts and rankings of LIS faculty: Web of Science versus Scopus and Google Scholar. Journal of the American Society for Information Science and Technology 58(13/August): 21052125. 